\title{
Partisipasi Budaya Komunitas Cosplay Lampung Pada Facebook
}

\author{
Oleh: \\ Fitriyanti $^{1}$ \& Fine Sifaninda ${ }^{2}$ \\ (e-Mail: fitiryanti@radenintan.ac.id) \\ ${ }^{1}$ Dosen Fakultas Dakwah dan Komunikasi Universitas Islam Negeri Raden Intan Lampung, \\ ${ }^{2}$ Mahasiswa Ilmu Komunikasi Universitas Tulang Bawang Lampung.
}

\begin{abstract}
Abstrak
Penelitian ini berjudul "Budaya Partisipasi Komunitas Cosplay Lampung Pada Facebook", tujuan dan kegunaan penelitian ini adalah untuk mengetahui bagaimana kontribusi anggota komunitas Cosplay Lampung dalam memanfaatkan media sosial Facebook. Penelitian ini menggunakan metode deskriptif dengan jenis kualitatif. Landasan teori yang digunakan dalam penelitian ini adalah Teori Participatory Culture oleh Henry Jenkins. Metode pengumpulan data yang digunakan adalah dengan wawancara, observasi, dan dokumentasi. Hasil dari penelitian ini yaitu dapat dilihat dari keanggotaan yang bersifat bebas, akrab dan kekeluargaan, kemudian kreatifitas berupa karya pembuatan kostum hingga karya digital, kontribusi selanjutnya yaitu kerjasama mengadakan event guna mempererat solidaritas, hingga membuat media baru yaitu instagram dengan tujuan eksistensi komunitas.
\end{abstract}

Kata Kunci: Facebook, Komunitas, Participatory culture

\section{PENDAHULUAN}

Media sosial banyak digunakan karena biaya yang dikeluarkan relatif sedikit, untuk mengaksesnya pun sekarang sangat mudah sekali. Sehingga tak sedikit yang memanfaatkan kekuatan Facebook sebagai sarana saling berbagi dan membuka ruang informasi baru untuk masyarakat dan bermunculannya komunitas online. Komunitas tersebut terbentuk dikarenakan saling terhubungnya beberapa user internet yang memiliki kesamaan latar belakang, kebutuhan serta ketertarikan.

Internet memungkinkan orang secara pribadi untuk menciptakan dan mempublikasi media melalui internet. Budaya baru ini menghubungkan internet yang digambarkan sebagai web 2.0. Dalam budaya partisipatif 'orang-orang muda secara kreatif merespon signal-signal elektronik dan komoditas- komoditas budaya' Meningkatnya akses ke internet telah menjadi suatu bagian integral dalam ekspansi budaya karena meningkatkan kemampuan orang bekerja kolaboratif mengembangkan serta menyebarkan berita, ide dan karya-karya kreatif dan berhubungan dengan orang yang memiliki tujuan dan kepentingan yang sama.

Salah satunya adalah komunitas Cosplay Lampung yang menjadi salah satu bagian dari cyber society, kegiatan interaksi pada komunitas ini hampir lebih banyak dilakukan melalui media sosial daripada interaksi konvensional tatap muka. Dalam aksesnya pada Facebook, komunitas cosplay lampung ini membentuk grup. sehingga kegiatan komunitas terfokus dalam grup tersebut. Grup Facebook merupakan media sharing dan bertukar informasi antar anggota tentang event, anime, manga, cosplay, maupun saling bertukar fikiran.

Komunitas Cosplay Lampung merupakan komunitas yang bergerak di suatu event dengan mengenakan pakaian serta pernak pernik dan rias wajah seperti yang dikenakan tokoh- tokoh anime, manga \& game. Karena para anggota komunitas Cosplay Lampung hanya bertemu pada event- event tertentu, maka proses interaksi 
dan perkumpulan anggota komunitas ini lebih banyak aktif dalam grup Facebook Cosplay Lampung.

Ketika seseorang bergabung dalam suatu komunitas online maka meraka telah dianggap menjadi salah satu bagian dari komunitas tersebut. Pada tingkatan pengguna apapu mereka menganggap atu memiliki keyakinan bahwa mereka telah mendapat informasi dan menjadi bagian dari komunitas tersebut. Jenkins(2009). Karena adanya rasa solidaritas yang tinggi serta pengakuan satu sama lain membuat anggota komunitas cosplay lampung saling berkontribusi. Adapun rumusan masalah yang diteliti adalah Bagaimana kontribusi komunitas Cosplay Lampung dalam Pemanfaatan media sosial Facebook?

Participatory Culture oleh Henry Jenkins (2009) menggambarkan bahwa individu dalam media sosial tidak hanya sebagai konsumen akan tetapi dapat bertindak sebagai produsen yang juga dapat menghasilkan sesuatu yang dapat meningkatkan interaktif dalam menggunakan sosial media.

\section{METODE PENELITIAN}

Jenis penelitian ini adalah penelitian deskriptif kualitatif. (Bogdan dan Taylo 1975:5) dalam Moleong (2010:4) mendefinisikan metodologi penelitian kualitatif sebagai prosedur penelitian yang menghasilkan data deskriptif berupa kata kata tertulis atau lisan dari orang-orang dan perilaku yang dapat diamati Pendekatan ini diarahkan pada latar dan individu tersebut secara holistik (utuh).

Dengan menggunakan metode deskriptif, peneliti menganalisa data yang dikumpulkan adalah berupa kata-kata, gambar, dan bukan angka- angka. Data tersebut mungkin berasal dari naskah wawancara, catatan lapangan, foto, videotape, dokumen pribadi, catatan atau memo, dan dokkumen resmi lainnya (Moleong, 2010:11).

Dalam mengumpulkan data untuk kepentingan penelitian ini, peneliti menggunakan berbagai macam metode. Berikut ini metode yang digunakan yaitu:

\section{Observasi}

Dengan metode ini. peneliti dimungkinkan melihat serta mengamati sendiri, kemudia mencatat perilaku serta kejadian yang telah terjadi sebenarnya Pada dasamya, melalui metode ini memungkinkan penelit merasakan apa yang dirasakan oleh objek penelitian pada waktu itu sehingga tidak menutup kemingkinan apabila peneliti menjadi sumber data. Memungkinkan pembentukan pengetahuan yang diketahui bersama, baik dari pihaknya maupun dari pihak subjek (Moleong 2010:175)

\section{Wawancara}

Pada penelitian ini, kegiatan wawancara dilakukan dengan jenis wawancara terstruktur. Dengan melakukan wawancara secara terstruktur peneli ingin mendapatkan data dan informasi yang lebih spesifik. Wawancara dilakukan dengan mewawancarai anggota grup facebook cosplay Lampung baik secara online maupun secara offline.

\section{Dokumentasi}

Metode ini dilakukan dengan cara mengumpulkan data yang berkaitan dengan penelitian baik dari buku, jurnal, surat kabar, majalah, foto, rekaman, video, ataupun internet. Data yang diperoleh dari metode dokumentasi diharapkan mampu mendukung proses analisis data. Salah satu kegiatan dokumentasi yang dilakukan adalah mengumpulkan data dari posting dalah grup.

Tekhnik analisa data yang digunakan dalam penelitian ini Peneliti menggunakan 
analisis interactive model yang dikemukakan oleh Miles dan Huberman (1994) dalam Pawito (2007:104). Teknik analisis ini memiliki tiga komponen yaiu:

\section{Reduksi data}

Dimaksudkan bahwa dalam tahap ini sebagai proses pemilihan data dan informasi yang telah didapatkan selama melakukan penelitian di lapangan. Dalam tahap ini peneliti fokus pada penyederhanaan data yang diperoleh. Setelah data yang diperoleh mampu diringkas, peneliti dapat menemukan konsep-konsep serta pola- pola data yang diinginkan yang kemudian dirancang dalam bentuk hasil analisa akhir. Pawito (2007:104).

\section{Penyajian data}

Merupakan sebuah proses yang menyajikan data pcnelitian dalam sebuah kesatuan yaitu hasil akhir penelitian melalui kalimat yang disusun secara sistematis dan logis sehingga mudah untuk dipahami. Oleh karena itulah sangat diperlukan penyajian data yang jelas dan sistematis dalam membantu peneliti menyelesaikan pekerjaannya. Pawito (2007:104).

\section{Kesimpulan}

Merupakan implikasi dari prinsip induktif penelitian. Selain itu, kesimpulan diverifikasi selama penelitian langsung guna memperoleh kebenaran tentang sebuah data dan informasi. Secara, data dan informasi yang dipcrolch akan diuji kebenarannya, kekuatannya, serta kecocokan dengan tujuan sebagai media validitasnya.Pawito (2007:104).

\section{HASIL PENELITIAN}

Media sosial merupakan sebuah media online yang para penggunanya dengan mudah untuk berpartisipasi, berbagi, bekerjasama dan berkolaborasi untuk menciptakan kreasi, berfikir, berdebat, hingga menemukan teman baik. Dengan adanya media sosial facebooK komunitas cosplay lampung semakin eksis dan banyak yang ingin mengetahui bagaimana perkembangan serta informasi terkini dari komunitas cosplay lampung. Ketika seseorang bergabung dalam suatu komunitas online maka mereka telah dianggap menjadi salah satu bagian dari komunitas tersebut. Berikut ungkapan Ratna (24 Tahun):

\footnotetext{
"Untuk member-member cosplay baik lama maupun newbie asik dan easy going so enjoy jika berinteraksi dgn mereka.Jadi saya merasa di hargai dan keberadaan saya itu di akui dengan member lainnya. Mau berbagi juga leluasa sih karena ngerasa dianggap. ya saya membuat fanpage yang berguna untuk menambah jaringan atau fans hahaha.. dan yang saya tau sih anggota lain buat konten youtube yg isinya cosplay lampung." (Wawancara dengan Ratna, anggota komunitas cosplay lampung pada 15 Mei 2019)

Berikut pengakuan Feiga (22 Tahun):

"Kerjasama jelas ada, saya rasa itu salah satu tujuan grup ini dibuat, karna dalam setiap event yang akan diselenggarakan member Terkait sangat antusias demi terselenggaranya event tersebut, baik dari mapping, dekorasi, sponsorship dll. Media lain jelas ada seperti grup di Line, WA, tujuannya agar lebih memudahkan dan tidak memakan terlalu banyak kuota karena info yang dibutuhkan terfokus pada satu media" (Wawancara dengan Feiga, anggota komunitas cosplay lampung pada 14 Mei 2019)
}

Dari hasil analisis wawancara di atas dapat diketahui bahwa anggota dalam komunitas Cosplay Lampung sangat interaktif dalam menggunakan media sosialnya, hal ini berjalan sesuai dengan teori Partisipasi budaya menurut Jenkins(2009) yaitu:

1. Keanggotaan bersifat bebas, akrab dan kekeluargaan. (Affiliations)

Seperti analisis wawancara Ratna (25tahun) selaku anggota cosplay lampung, beliau mengatakan bahwa didalam grup 
cosplay lampung dirinya merasa nyaman dan leluasa untuk saling berbagi karena para anggotanya cukup terbuka dan mudah untuk diajak berinteraksi.

Pengakuan para sesama anggota grup serta dihargai keberadaan anggota lainnya akan merasa anggota betah serta leluasa untuk saling berbagi. Keanggotaan dalam komunitas cosplay Lampung bersifat bebas, akrab, dan kekeluargaan. Interaksi yang terjalin dalam komunitas cosplay lampung tidak begitu sulit dilakukan karena semua anggota sudah saling bertemu pada suatu acara. Hal tersebut diatas sesuai dengan bentuk partisipasi budaya oleh jenkins(2009) affiliations atau afiliasi yaitu tergabung dan ikut serta dalam keanggotaan baik informal maupun formal.

2. Kreatifitas anggota berupa karya pembuatan kostum hingga karya digital (Expressions)

Memproduksi kreatif baru merupakan bentuk dari teori partisipasi Jenkins (2009) dalam suatu komunitas dari banyaknya interaksi yang terjadi akan menghasilkan sesuatu yang kreatif. Maksud dari kreatif baru yaitu ekspresi yang merupakan memperlihatkan serta menyatakan maksud, gagasan, perasaan dan sebagainya dalam bentuk karya. Seperti hasil analisis Feiga (22tahun) beliau mengungkapkan bahwa dalam komunitas cosplay Lampung anggotanya tidak dibatasi untuk berkarya, Kreatif yang dibuat pada anggota cosplay Lampung cukup banyak untuk ukuran grup provinsi, mulai dari live streaming, informasi seputar anime, hingga membuat Fanart.

3. Kerjasama mengadakan event guna mempererat solidaritas (Collaborative Problem Solving)

Seperti pada analisis hasil wawancara Feiga (22tahun) selaku anggota komunitas cosplay lampung. Kerjasama yang dilakukan oleh anggota komunitas cosplay lampung selain dalam hal pembuatan kostum baik kostum kain maupun kostum dari bahan lain, komunitas cosplay Lampung juga membuat kerjasama dalam membuat suatu event. Kerjasama dalam membuat event ini selain bertujuan untuk anggotanya saling bertemu pada acara, berguna juga untuk melatih anggota dalam hal solidaritas, kesabaran, memperbanyak relasi, serta pengalaman bagi anggota yang bekerjasama.

\section{Membuat Youtube cosplay Lampung dengan tujuan Eksistensi Komunitas (Circulations).}

Seperti analisis wawancara Ratna (25tahun) selaku anggota cosplay lampung, beliau menuturkan bahwa telah membuat fans page yang berguna untuk menambah jaringan relasi maupun fans. Konten YouTube maupun Fans page pada Instagram selain berguna dalam hal eksistensi komunitas namun berguna juga untuk anggotanya sebagai personal branding atau citra diri. Dalam hal ini dapat dipastikan bahwa alur media yang dibuat merupakan suatu aliran media yang saling berhubungan, hal itu senada dengan bentuk partisipasi menurut Jenkins (2002) yaitu Circulation atau sirkulasi.

\section{KESIMPULAN}

Kontribusi anggota kimunitas Cosplay Lampung dalam Pemanfaatan media sosial dapat dilihat dari keanggotaan (Affiliations) yang bersifat harmonis dan kekeluargaan, sesama anggota saling berinteraksi tanpa membedakan anggota lama ataupun baru serta pengakuan dari anggota lainnya. Banyaknya interaksi yang terjadi membuat anggota berfikir kreatif untuk menbuat suatu karya individu, karya (Expressions) tersebut berupa siaran langsung facebook, blog pribadi, serta Fanart yang berguna untuk personal branding individunya.

$$
\text { Selain itu Kerjasamapun }
$$
(Collaborative) dilakukan dalam komunitas 
ini yaitu berupa membuat kostum, event, hingga berkolaborasi membuat suatu media baru (Circulations). Media baru tersebut yaitu konten YouTube, Instagram, dan Fanspage yang isinya saling berhubungan.

\section{DAFTAR PUSTAKA}

Effendi,Onong Uchjana. 2003. Ilmu komunikasi teori dan praktek, Bandung: PT. Remaja rosdakarya.

Hermawan, Kertajaya. 2008. Arti komunitas, Jakarta : Gramedia Pustaka Utama

Jalaludin Rahmat 2005. metode penelitian komunikasi, Bandung: PT. Remaja rosdakarya.

Littlejohn, W.Stephen. 2011. Teori Komunikasi, Jakarta :Salemba Humanika

Moelong, Lexy J. 2010. Metodologi Penelitian Kualitatif. Bandung: PT.Remaja Rosdakarya

Jurnal:

Maya, Juwita Sari. 2014. " Konsep Diri Remaja Pengguna Facebook Di SMA N 1 Puri Mojokerto". oleh Maya Juwita, Mojokerto.

Sumber Lain/Internet :

Vanina Delobelle. 2008.

www.vaninadelobelle.com, Corporate

Community Management, May 2008 diakses Minggu 25 Agustus 2019, 09:41 AM. 